https://doi.org/10.18485/cosic_dobrica.2018.ch23

821.163.41.09 Ћосић Д.

371.3::821.163.41

\author{
ВЕљКО Ж. БРБОРИЋ* \\ Универзитет у Београду \\ Филолошки факултет
}

\title{
КЊИЖЕВНО ДЕЛО ДОБРИЦЕ ЋОСИЋА У НАСТАВИ*
}

\begin{abstract}
У раду се говори о делу Добрице Ћосића у настави. Прегледаћемо актуелне наставне планове и програме и видети заступљеност дела Добрице Ћосића у настави. Истовремено ћемо видети и какав су статус имала његова дела у настави друге половине двадесетог века, тј. када је Д. Ћосић ушао у ученичку лектиру и какве су се промене дешавале од тада до данас. После тога ћемо прегледати уџбеничку литературу и видети какав је њен приступ делу познатог писца. То ће, по нашем мишљењу, бити довољно да се изведу одговарајући закључци о месту и улози дела Добрице Ћосића у нашим основним и средњим школама, односно о заступљености његових дела у настави.
\end{abstract}

Кључне речи: Добрица Ћосић, наставни програм, читанке, основна школа, средња школа, уџбеници и приручници.

\section{1. Увод}

Од устројства школства, у настави књижевности, престижно је било да се дело неког писца нађе у школској лектири и буде обавезно наставно штиво. Није спорно да у школску лектиру улазе најбоља и најрепрезентативнија дела домаће књижевности и изабрана дела светске књижевности, али је било и периода када су у школску лектиру улазила дела „ангажоване” књижевности. То није само код нас, такве случајеве познају и друге културе. Ипак, већини дела заступљених у школској лектири заслужено је припадало такво место, али се не могу искључити и другачији случајеви, мада њихов број није био превелик. У Лексикону образовних термина уз одредницу лекииира налазимо следеће објашњење: „ЛЕКТИРА (франц. lecture - читање, штиво) - текстови

•brboricv@eunet.rs

" Рад је резултат истраживања на пројекту Срйски језик и њеі̄ови ресурси: йеорија, ойис и ирримена (бр. 178006), који финансира Министарство просвете, науке и технолошког развоја Републике Србије. 
различитог садржаја ( $\rightarrow$ књиге $\rightarrow$ часописи, новине) који се читају из забаве или ради учења. Осим слободно изабраних, постоји и обавезна, школска л., одабрана према узрасту ученика, која помаже њиховом интелектуалном развоју и развијању естетских критеријума. За узраст основне школе бирају се књижевни и ванкњижевни $\rightarrow$ текстови усклађени с програмом наставе $\rightarrow$ матерњег језика и $\rightarrow$ књижевности, у функцији развијања језичких компетенција. У средњој школи програм планира л. уважавајући књижевноисторијску хронологију темељних $\rightarrow$ дела националне и опште књижевне баштине. У том школском периоду л. поставља основе књижевној и општој $\rightarrow$ култури ученика. Издање школске л. одговарајуће је опремљено неопходним објашњењима за разумевање текста $\rightarrow$ и контекста дела, чиме се пружају основни подстицаји за $\rightarrow$ интерпретацију" (ЛОТ 2014: 350). Ако пажљиво прочитамо одредницу из поменутог лексикона, није тешко закључити да књижевно дело у школску лектиру не улази лако и да су критеријуми за такав поступак строги, као и да се од лектире очекује да „поставља основе књижевној и општој култури ученика". Лектира подразумева читање, доживљавање и анализу књижевних дела, као и друге подстицаје и размишљања током тог процеса. Да се у школску лектиру не улази тако лако, показује данашњи статус савремених писаца у настави, тј. наставним програмима за основну и средњу школу. ${ }^{1}$ У свим културама и свим школским системима одувек је било престижно бити писац чије се дело изучава у школи. ${ }^{2}$ Добрица Ћосић је постао школски писац још пре шест деценија (крајем шесте деценије двадесетог века) и од тада се наши ученици сусрећу са његовим књижевним делом. Према актуелним наставним плановима и програмима данас се дело Добрице Ћосића изучава у осмом разреду основне школе и четвртом разреду гимназије. Тако можемо рећи да су сви они који су рођени у Србији од средине прошлог века, а за њих је основна школа била обавезна, упознати са књижевним делом Добрице Ћосића и они су читали барем неко његово књижевно дело. То су данас сви они који имају мање од седамдесет година и то значи да је већина грађана Србије читала бар неко од дела нашег писца. Овде се мисли само на читање по школском захтеву.

${ }^{1}$ Наши средњошколци се данас од савремених (живих) писаца сусрећу само са делом Горана Петровића, Душана Ковачевића и Матије Бећковића.

${ }^{2}$ Постати школски писац доноси одређене погодности. Овде ћемо издвојити само две: постајете познати свеукупној школској популацији, а конкретно дело се штампа у огромним тиражима, јер се очекује да све библиотеке, посебно школске, набављају књижевна дела, а и ученици, по правилу, набављају школску лектиру. Она је раније била обавезни део уџбеничког комплета. 


\section{2. Дело Добрице Ћосића у наставном плану и програму}

Дело Добрице Ћосића ушло је у наше наставне програме недуго по објављивању романа Далеко је сунще. Овај роман је објављен 1951. године и већ крајем деценије у којој је објављен овај роман бива уврштен у наставни програм за осми разред основне школе. ${ }^{3}$ Касније су у наставне програме стигла и нека друга дела Д. Ћосића, а у актуелним програмима данас сусрећемо три романа. Роман Далеко је суние крајем двадесетог века замењен је романом Деобе. Наиме, у осмом разреду, у списку лектире, налазимо роман Деобе (одломак), док се у четвртом разреду

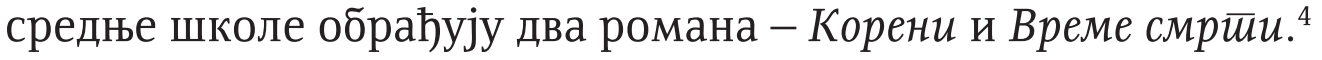

Већ неколико деценија Добрица Ћосић је код нас као писац и хваљен и оспораван. Наше је мишљење да је он један од најзначајних српских писаца друге половине двадесетог века. Ипак, његово књижевно дело трпело је и још увек трпи повремене критике различите садржине. Тако и данас сусрећемо супротстављене ставове - од оних да му није место у наставним програмима до оних који тврде да није довољно заступљен у нашем образовном систему. То и даље остаје отворено питање. Сматрамо да је на таква тумачења утицао живот Добрице Ћосића, односно његов политички ангажман, и то у два наврата.

\section{3. Дело Добрице Ћосића у настави}

Поред наставних програма, о заступљености дела Добрице Ћосића у нашем систему школства речито говори и основна уџбеничка литература. Покушаћемо да је представимо тако што ћемо узети по три читанке за осми разред основне школе и три читанке за четврти разред средње школе. Реч је о читанкама различитих аутора и различитих издавача (Завод за уџбенике, Клет и Логос). Ево уџбеника који ће послужити за нашу анализу:

а) Читанке за основну школу:

1. Љиљана Бајић и Зона Мркаљ, Читианка за 8. paзреg основне школе, Београд, Завод за уџбенике, 2010.

${ }^{3}$ Наставни планови и програми су службени документи, доносе их просветне власти и они су основа сваке ваљане наставе. Док планови доносе информације о томе који се предмети изучавају у одређеном разреду и њихов број часова (недељни и годишњи), програми одређују садржаје планова и у настави књижевности врло прецизно доносе имена писаца и њихова дела која се обрађују у појединим разредима основне и средње школе. Истина, понекад поред обавезних текстова налазимо и факултативне.

${ }^{4}$ По правилу се у основној школи обрађују одломци из обимнијих дела, док се у средњој школи обрађују дела у целини. 
2. Зорица Несторовић и Златко Грушановић, Читианка за 8. paзpeg основне школе, Београд, Клет, 2016.

3. Наташа Станковић Шошо, Читианка за 8. paзреg основне школе, Београд, Логос, 2016.

б) Читанке за средњу школу:

4. Љиљана Николић и Босиљка Милић, Читианка са књижевнотееоријским йојмовима за IV разреg среgюе школе, Београд, Завод за уџбенике, 2016.

5. Љиљана Бајић, Миодраг Павловић, Зона Мркаљ, Чийанка за

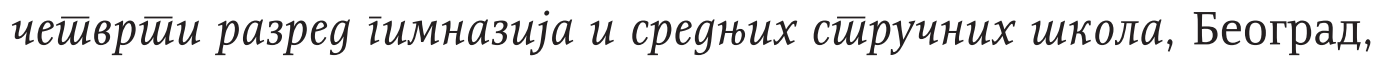
Клет, 2016.

6. Предраг Петровић, Мина Ђурић, Бошко Сувајџић и Наташа

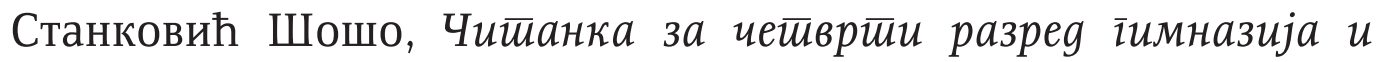
среgюих стируиних школа, Београд, Логос, 2016.

\section{1. Биог̄рафија Добрище Ћосића у нашим иитанкама}

Методичка литература је у неким ранијим периодима различито приступала биографији писца чије се дело обрађује у школи. Сусретали смо и тумачења да се дело може обрађивати без познавања живота и рада писца, да је довољно знати само ауторство. Ипак, такво мишљење није могло опстати и данас се сматра да ученици морају знати основне податке о животу и делу писца. Код нас се у читанкама доносе основни подаци о животу и делу писца, те податке састављају аутори читанки. ${ }^{5}$ Није спорно да су ученици у основној школи упућени, по правилу, само на читанке, док средњошколци поред читанки имају и лектиру и додатну литературу. Често се у тој литератури, у предговорима и поговорима, може наћи доста података о животу и раду писца. Као што знамо, времена су се променила и данас ученици лако долазе до тих података, посебно ако су за то мотивисани. ${ }^{6}$

Свакако је отворено питање које податке о Добрици Ћосићу предочити ученицима осмог разреда, а које нашим матурантима. Одговор

${ }^{5}$ Обично се, на крају читанке, доноси азбучник писаца, али се, посебно у новије време, сусреће и другачији приступ, тако да се подаци о животу и раду писца налазе уз само дело. Понекад биобиблиографске податке о писцу можемо сусрести и уз дело и на крају читанке.

${ }^{6}$ Некада су учионице биле украшене портретима и фотографијама писаца (понеке их имају и данас), а фотографије се неретко налазе и у читанкама. Сматра се да је добро када ученици могу препознати лик писца. Модерна техничка средства (рачунари и телефони) данас могу ученицима олакшати ову врсту сазнања. С мало труда, врло брзо и лако долази се до релевантних података о писцима. 
није тако једноставан. Посебно ако знамо какав је животни пут Добрице Ћосића. Он је рођен и одрастао у поморавском селу Велика Дренова код Трстеника 1921. године у богатој сеоској породици чији су се мушки чланови занимали за политичка и социјална питања у тадашњој држави. Разуме се да је на њега утицала патријархална култура, али и то да је био под утицајем комунистичке идеологије. Са комунистичким идејама упознао се још као ученик средње пољопривредне школе, а читао је и дела Николаја Велимировића. Учесник је Другог светског рата, рано се прикључио комунистичком покрету. Средином рата (1943) постао је политички комесар Расинског партизанског одреда. После Другог светског рата обављао је различите дужности, био је и народни посланик, али се 1968. године због критике владајућег система повукао и добио атрибут српског националисте. Често се каже да је од 1968. до 1992. био комунистички дисидент, вођа незваничне опозиције и нека врста демократског националисте, залагао се за људска права, критиковао је бирократију, осуђивао је култ личности и 1984. године је основао Одбор за одбрану слободе мисли и изражавања. Средином 1992. Ћосић се поново политички ангажовао и био је први председник Савезне Републике Југославије. Међутим, већ у другој половини 1993. године смењен је са те функције. Поново се вратио литератури, добитник је бројних књижевних награда, међу њима се издвајају НИН-ова награда за роман године и награда Народне библиотеке Србије за најчитанију књигу. ${ }^{7}$ Био је члан САНУ и до смрти је живео у Београду. Објавио је велики број књига, претежно романа, али и других текстова.

Поставља се питање шта је потребно од ових података из живота понудити ученицима на крају основног, а шта на крају средњошколског образовања. Због тога смо прегледали наведене читанке и овде доносимо податке о животу и делу Д. Ћосића у њима.

Чишанка за осми разреg основне школе Завода за уџбенике аутора Љиљане Бајић и Зоне Мркаљ о Д. Ћосићу нуди следеће податке:

Ћосић, Добрица (1921), савремени српски романсијер, чије је дело обележило последњи период, другу половину XX века, и наше време. Био је учесник у Другом светском рату, а као хуманиста и политичар до данас је ангажован у друштвеном животу земље. Његово књижевно дело одликује се проблемским приступом историјској тематици и модерним приповедачким поступком и стилом. Ове новине најављене су у роману Корени. Са њима почиње циклус романа који пружају романсирану историју модерне Србије: Деобе (1961), Време смриии (четири књиге), Време зла (три-

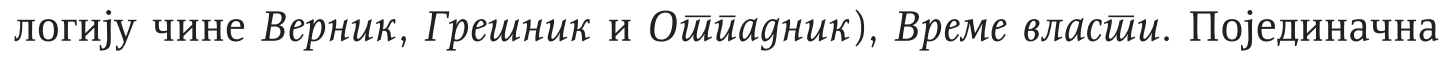

${ }^{7}$ Престижну НИН-ову награду за роман године Д. Ћосић добио је два пута - 1954. године за роман Корени и 1961. за роман Деобе. 
дела у циклусу спаја замисао о роману као историји земље и народа и присуство ликова који су повезани породичним стаблима (Бајић и Мркаљ 2010: 214). ${ }^{8}$

Последњих неколико година наши основци највише користе уџбеничке комплете за Српски језик издавачке куће Клет. У уџбенику за осми разред о Д. Ћосићу сусрећемо ове податке:

Рођен је 1921. године у Великој Дренови код Трстеника. Завршио је Вишу политичку школу у Београду. У току Народноослободилачке борбе био је политички комесар у Ресавском партизанском одреду. Након рада обављао је различите функције у друштвеном и политичком животу земље, између осталог и функцију председника Југославије. У српску књижевност ушао је романом Далеко је суние (1951). Најчешће пише о догађајима из српске историје XIX и XX века. Његове основне теме су судбина народа и појединца у тешким, бурним и сложеним временима. О томе говоре романи Корени, Време смрйи, Време зла (трилогија Верник,

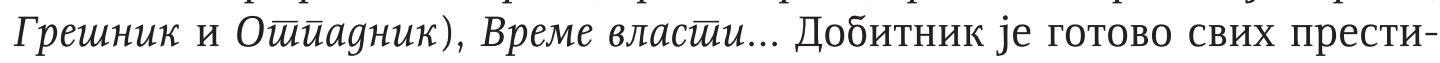
жних награда за свој рад у области књижевности и културе. Својим делом обележио је другу половину двадесетога века у развоју српске књижевности (Несторовић и Грушановић 2016: 224). ${ }^{9}$

Трећи консултовани уџбеник је читанка издавачке куће Логос и она уз обраду одломка из Деоба доноси белешку о ауйору са следећим садржајем:

Добрица Ћосић (1921-2014), савремени српски писац. Школовао се у родном месту, Алексинцу и Букову, где је завршио средњу пољопривредну школу. После рата, у коме је учествовао од 1941. године, завршио је Новинарску школу и Вишу политичку школу у Београду. Од 1992. до 1993. био је председник Савезне Републике Југославије. Члан Српске академије наука и уметности. Објавио је романе: Далеко је суние (1951),

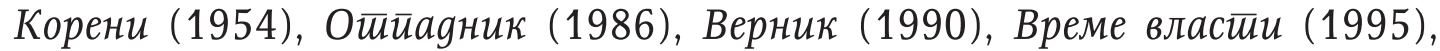
Време зла (1996) и друге (Станковић Шошо 2016: 195).

Није тешко закључити да се у трима консултованим читанкама за осми разред основне школе аутори неједнако односе према животу и делу Добрице Ћосића. Чини се да читанка издавачке куће Логос нуди превише година везаних за живот писца и мислимо да то није потребно; овде се такође говори о његовом политичком ангажману и сматрамо да је то нашим основцима непотребно. Читанка издавачке куће Клет наводи и то да је аутор „био је политички комесар у Ресавском партизанском

${ }^{8}$ Последње издање овог уџбеника је из 2010. године. Стога, нема податка да је писац умро.

${ }^{9}$ Нејасно је зашто у издању из 2016. године недостаје податак о смрти писца. 
одреду", па нам се ни ово не чини важним податком за тумачење његовог дела на овом узрасту. Једино читанка Завода за уџбенике наводи да је Д. Ћосић написао и роман Деобе, роман из кога се обрађује одломак, тај податак је изостао код друга два издавача, па можемо рећи да је биографија писца најбоље обрађена у овом уџбенику и да је овај приступ најпримеренији за ученике осмог разреда основне школе.

Очекивано је да средњошколске читанке нуде опширнија сазнања о животу и раду писца. Читанка Завода за уџбенике (аутори Љиљана Николић и Босиљка Милић) ${ }^{10}$ скоро да не говори о животу, већ само о делу Д. Ћосића:

Ћосић, Добрица (1921), модерни савремени романсијер, члан САНУ. Низом романа обухватио је друштвене и историјске, духовне и културне токове српског народа у раздобљу од скоро 150 година, следећи при том европску традицију ангажованог писца. Добитник је многих значајних награда. Значајнија дела - Далеко је суние (1951), Корени (1954), Деобе

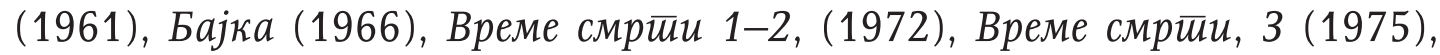

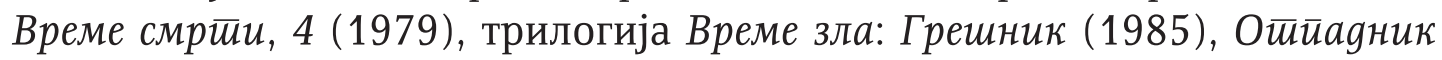
(1986) и Верник (1990), Време власиии (1995); књиге публицистичке прозе; Сабрана дела у 25 томова (2000) (Николић и Милић 2016: 256). ${ }^{11}$

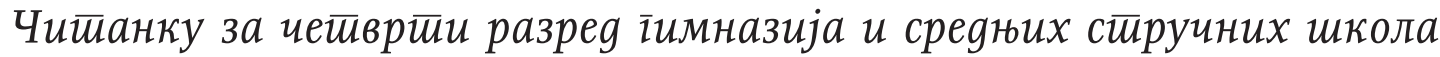
издавачке куће Клет потписују љ. Бајић, М. Павловић и З. Мркаљ. Консултовали смо прво издање из 2016. године и о Д. Ћосићу налазимо следеће податке:

Добрица Ћосић (1921-2014), модерни романсијер и једна од најутицајних фигура у српском друштву с краја 20. и почетком 21. века. Био је члан САНУ. Добитник је значајних књижевних награда. НИН-ову награду добио је 1954. године за роман Корени и 1961. за Деобе. У својим романима описао је друштвене промене у српском народу (у периоду од око 150 година). Његови најзначајнији романи су: - Далеко је суние (1951), Корени

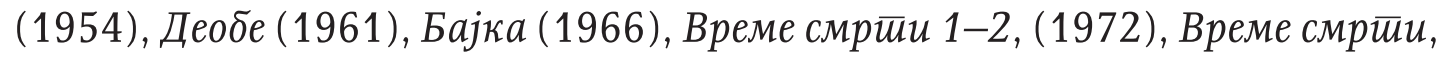
3 (1975), Време смриич, 4 (1979), трилогија Време зла: Грешник (1985),

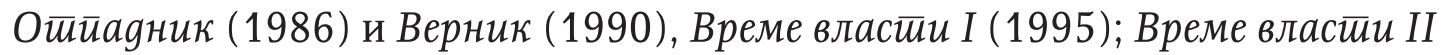
(2007). Добитник је скоро свих књижевних награда и признања, а његова дела су преведена на тридесетак језика (Бајић и др. 2016: 388). ${ }^{12}$

${ }^{10}$ Консултовали смо 19. издање, штампано 2016. године (разуме се да је у реиздањима било мањих допуна). Ова читанка је у настави више од две деценије. То није тако честа појава.

11 Д. Ћосић је умро 2014. године, а ово издање читанке је штампано 2016. Није нам јасно зашто је изостао податак да је писац преминуо.

12 Податак да су дела Д. Ћосића преведена на тридесетак језика важан је и он додатно говори о квалитету његовог књижевног дела. 
Прво издање уџбеника издавачке куће Логос из 2016. Чишинка за

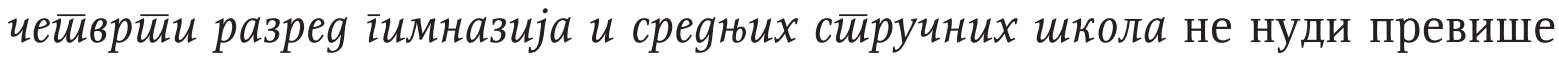
података о писцу:

Добрица Ћосић (1921-2014), значајан савремени српски писац, романсијер, редовни члан САНУ. Рођен је 1921. године у селу Велика Дренова код Трстеника. Био је председник Савезне Републике Југославије од 1992. до 1993. године. Први је добитник Нинове награде 1954. године за роман Корени. У свом књижевном опусу бавио се питањима историје, друштва, средине, културе, комбинујући традиционалне и модерне приступе књижевном тексту. Ћосићево књижевно дело одликује се интересовањима за историјску тематику, као и тежњом ка модерним приповедачким поступцима. Написао је романе Далеко је сунще (1951), Корени (1954), Деобе (1961), Време смриши I-IV (1972-1979), Време зла-Грешник (1985),

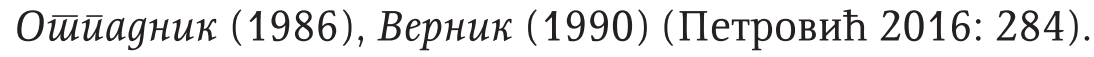

Ни у уџбеницима за четврти разред средње школе није тешко приметити неуједначен приступ животу и делу Добрице Ћосића. Сматрамо да је потребно да се нашим средњошколцима понуди више података из живота Д. Ћосића, као и да се објасни његово учешће у Другом светском рату, његов политички ангажман после рата и његово „дисиденство” у другој половини двадесетога века. Све то је значајно за разумевање књижевног дела Д. Ћосића. Убеђени смо да средњошколци морају знати више података о животу и делу нашег писца него што то нуде читанке и да није нужно инсистирати на великом броју година које су везане за живот и дело. Тако читанка издавачке куће Логос наводи 14 година уз његову биографију и то нам се чини неоправданим и непотребним. У неким издањима читанки из 2016. године нема податка да је писац преминуо и то не можемо оправдати, тај податак је лако унети и избећи евентуални неспоразум. То само сведочи да нам уџбеници нису довољно усклађени, посебно ако се узму у обзир биографије неких других писаца у истим

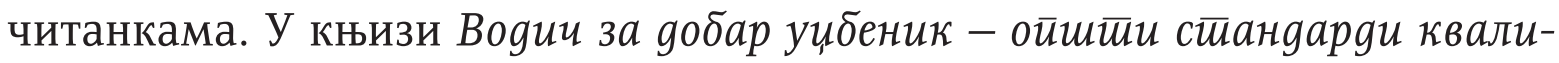
$\overline{\bar{u}} \overline{\bar{u}} а$ уцбеника јасно стоји: „Садржај уџбеника за одређени разред мора се постепено и логички настављати на садржај уџбеника истог предмета из претходних разреда, али мора и обезбедити основу за наставак учења тог предмета у наредним разредима" (Ивић и др. 2008: 79).

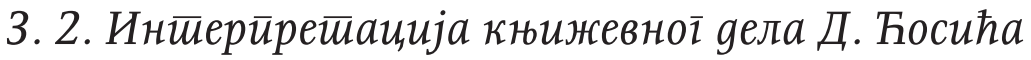 у читианкама}

Није спорно да су читанке основни уџбеници у настави књижевности, помоћу њих се ученици уводе у књижевност и њихова улога у тумачењу књижевних дела је незаобилазна. Наше читанке увек прво доносе 
уметничке текстове (у целини или њихове одломке), а потом сусрећемо књижевнонаучне и стручне текстове који су у функцији тумачења првих. Уз то, ови други текстови, чији су писци аутори читанки, доносе и тзв. дидактичко-методичку апаратуру. Ту прво налазимо питања за тумачење књижевних дела, али и друге подстицаје за тумачење књижевних дела, важних књижевнотеоријских појмова и најчешће објашњења непознатих речи и израза (Илић 1997: 112; Николић 1992: 52-53).

Чишанка за 8. pазреg основне школе (Завод за уџбенике) о делу Д. Ћосића говори само на три стране (Бајић и Мркаљ 2010: 110-112). Пре одломка налазимо кратко објашњење:

Ойкриће је прво, уводно поглавље романа Деобе Добрице Ћосића. У њему је приказана одмазда над народом после оружане акције партизанског одреда у којој је убијено или рањено више Немаца. Заробљени народ, заточен у сеоској цркви, страдаће када Немци активирају експлозив који су поставили у њене темеље (Бајић и Мркаљ 2010: 110).

Затим следи одломак, на нешто више од две стране, а потом обја-

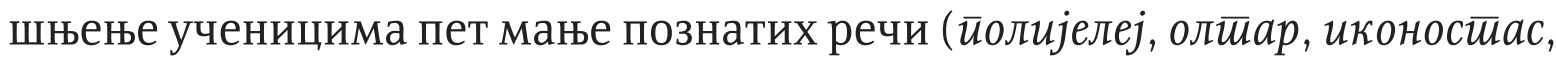
икона и канgило). Објашњења непознатих речи су јасна и коректна. Сле-

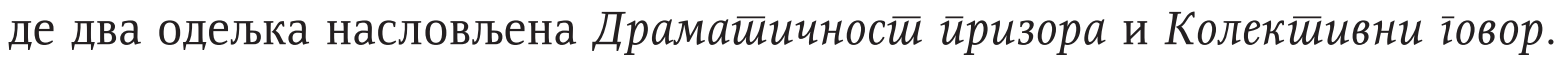

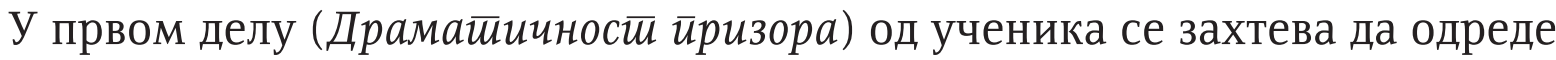

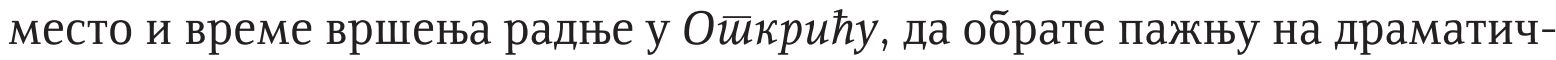
ност одломка, да доведу у везу намере Немаца и да објасне везу цркве и трагичног догађаја. Затим се од ученика очекује да проуче уметничка средства којима се дочарава слика цркве напуњене народом и да обрате пажњу на кретање светлости, игру сенки, крцкање иконостаса и детињи плач. У делу насловљеном као Колекйивни іовор ученицима се упућује захтев да одреде и образложе ко је јунак одломка, да обрате пажњу на колективни лик и на сличност и разлике између људи. Тражи се и да обрате пажњу на психолошке и емотивне мотиве и у речима и у понашању људи, с посебним освртом на речи које су девојке упутиле Немцима, као и да анализирају осећања и поруке одломка (Бајић и Мркаљ 2010: 112).

чишанка за осми разреg основне школе издавачке куће Клет за одломак из Деоба и његово објашњење одвојила је осам страна (Несторовић и Грушановић 2016: 217-224). Сусрећемо објашњење пре одломка које је нешто шире и не тиче се само романа Деобе:

После свог првог романа, Далеко је суние, Добрица Ћосић се 1961. године у роману Деобе враћа теми Другог светског рата. Средишња тема је подела у народу на партизане и четнике и последице до којих је довела.

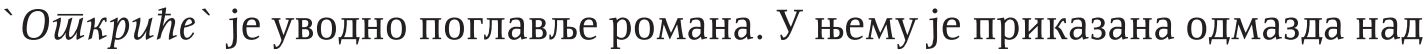
народом после партизанске акције у којој је убијено више Немаца. Ста- 
новници српског села Трнаве затворени су у цркву, у чије темеље је постављен експлозив (Несторовић и Грушановић 2016: 217).

Овде је наведен знатно дужи одломак од онога који се сусреће у Заводовом уџбенику. На маргини налазимо објашњење непознатих речи

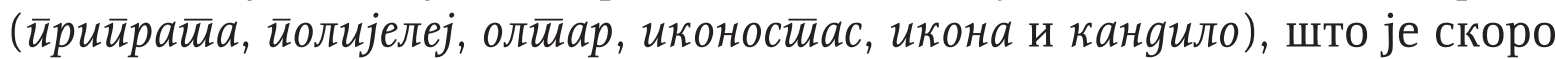
идентично претходно приказаном уџбенику. На целој страни је једна илустрација, али нам она не изгледа добро одабрана и прилагођена одломку. После одломка налазимо захтеве за тумачење одломка, они су коректни, а затим следи део насловљен као Појмовник и у њему обја-

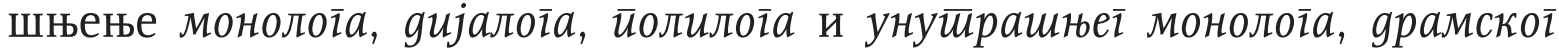
монолоїа и gрамскої gијалоїа. Сусрећемо и објашњење да је овај текст драматизован и да је неко време приказиван у Југословенском драмском позоришту, као и да је могуће читање по улогама и драматизација поменутога текста (одломка).

Читанка издавачке куће Логос о делу Д. Ћосића говори на пет страна (Станковић Шошо 2016: 191-195). Уз напомену да је у питању одломак из романа налазимо кратко објашњење: „Радња романа Деобе Добрице Ћосића временски је смештена у период Другог светског рата. У одломку који је пред тобом читаћеш о трагичној судбини мештана села Трнаве, које су Немци затворили у цркву коју су претходно минирали" (Станковић Шошо 2016: 191). Следи одломак, на више од две стране текста с једном, не баш превише успешном илустрацијом и, на маргини, објашњење четири непознате речи ( $\bar{u} о л и ј е л е ј, ~ о л и ̆ а р, ~ и к о н о с \overline{и а с ~ и ~ к а н g и-~}$ ло). Након текста одломка сусрећемо, на две стране, објашњења која се односе на роман, односно на одломак (Станковић Шошо 2016: 194-195). Поднаслови који ће помоћи тумачењу текста насловљени су на следећи

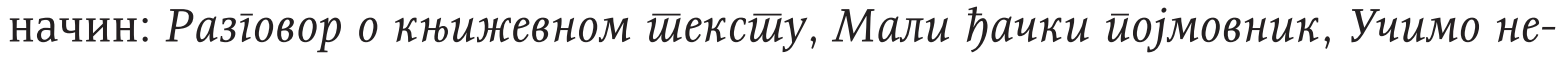
шйо ново, Применујемо научено и Из ризниче речи. Питања и објашњења која овде налазимо свакако ће помоћи тумачењу и разумевању одломка, али нам се чини да има и непотребних понављања. Тако сусрећемо објашњење шта је роман и када је настао, како делимо романе и слично. Верујемо да су ово ученици већ савладали и није нам јасно зашто је то наведено баш уз овај одломак.

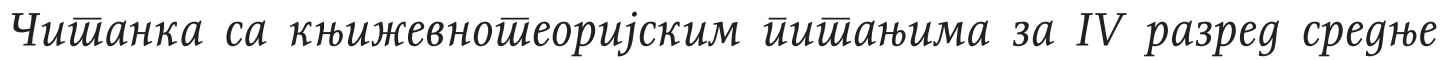
школе Завода за уџбенике о делу Д. Ћосића говори на 19 страна (Николић и Милић 2016: 167-185). Прво налазимо одломак из романа Корени на три стране, а пре текста одломка имамо кратко објашњење:

У роману Корени Добрица Ћосић слика историју раслојавања богате сеоске породице с краја XIX века, сукоб синова с оцем, грчевито настојање да се добије наследник да се лоза Катића продужи. У овом одломку при- 
казан је сукоб главног јунака Ђорђа с оцем Аћимом и његова немоћ изражена према жени Симки (Николић и Милић 2016: 167).

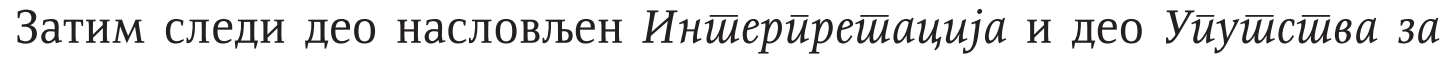
самосйалан pag, уз цитат Светлане Велмар Јанковић. Питања су, може се рећи, добро осмишљена, прилагођена реалним захтевима анализе и пружају добру основу за квалитетан рад на тексту.

Одломци из романа Време смрйи дати су на чак 13 страна овог уџбеника (Николић и Милић 2016: 172-184), а пре њих сусрећемо објашњење о роману:

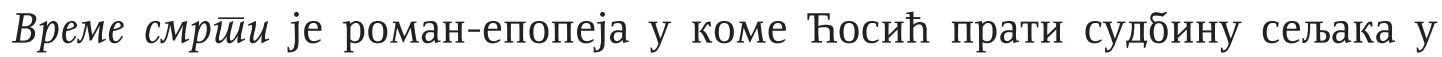
Првом светском рату. У средишту свога романа писац ставља суштинска питања народног опстанка: живот и смрт. Историјско-хронолошки ток Ћосићевог приповедања успешно се преплиће са генетичким. У средишту романа су две породице које потичу из села Прерова: Катићи и Дачићи, чије сте јунаке упознали у роману Корени. Три покољења Катића и два Дачића учествују у фабули епопеје - Катићи: Аћим, Ђорђе, Вукашин, Олга, Адам и Милена; Дачићи: Тола и његови синови Живко, Благоје, Алекса и Милоје. Њихове судбине су битне за остваривање уметничке концепције романа. Поред ових, Ћосић је у структури свога романа уградио велики број других ликова и историјских личности, од којих доминантно место има лик легендарног команданта армије, генерала Живојина Мишића (Николић и Милић 2016: 172). ${ }^{13}$

С обзиром на то да се у четвртом разреду обрађује роман у целини, нисмо сигурни да је потребно доносити поменуте одломке на чак 13 страна и верујемо да су одломци могли бити краћи, а да се на том месту нађу објашњења која ће бити од помоћи ученицима за разумевање романа и за његово тумачење на наставном часу.

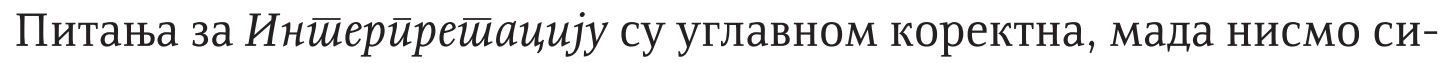
гурни да су нека од њих и оправдана, тако да нисмо убеђени да је потребно да се међу њима нађе и питање: „Потврдите примерима из романа Време смриич да је Ћосић хуманиста и антимилитариста", посебно због тога што је одговор на ово питање захтеван и ово би могло бити пре тема матурског рада, а не једно од питања за интерпретацију романа. Уз захтев да ученици упореде своје виђење српске интелигенције у Ћосићевом роману Време смрйи са проценом књижевне критике сусрећемо добро

${ }^{13}$ Одломци који су дати у уџбенику су из друге књиге романа Време смрйи под

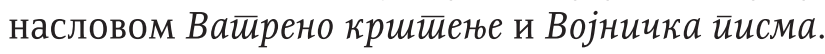


одабран цитат Витомира Вулетића с насловом Ђачки батальон (Николић и Милић 2016: 185). ${ }^{14}$

Читанка издавачке куће Клет о Ћосићу, тј. о романима Корени и Време смриии, говори на 22 стане (Бајић и др. 2016: 220-241). Прво се нуди прилично опширно образложење о роману Корени (ibid.: 220221), потом следе одломци из романа на десет страна уџбеника (ibid.: 221-230), те питања за Тумачење са следећим поднасловима: Глеguшйа

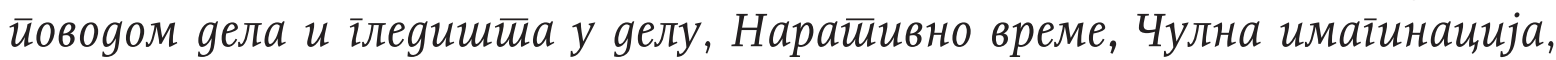
Оживљаване йојеgиностии, Он не долази кући као некаgа, Наg нейојеgеном вечером, У животиу немам нишйа сем gукайа и муке, Јунакиња Корена

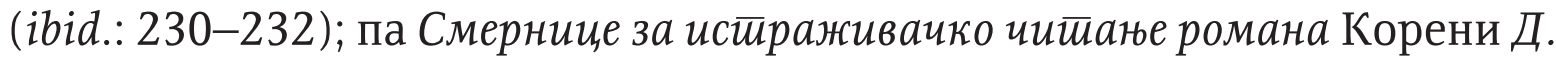
Ћоcuћa (ibid.: 233). На маргини, уз одломак, налазе се објашњења осамна-

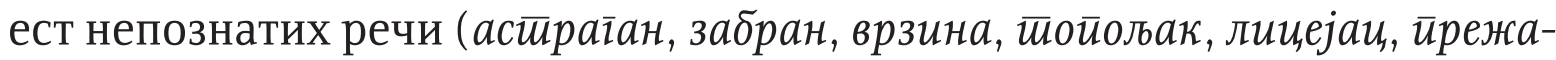

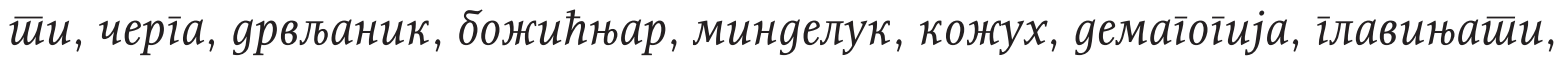

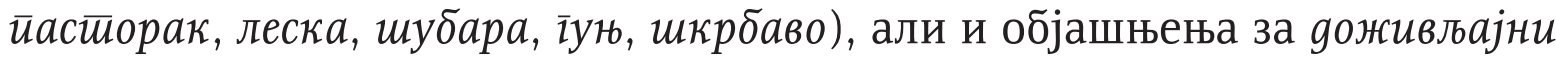

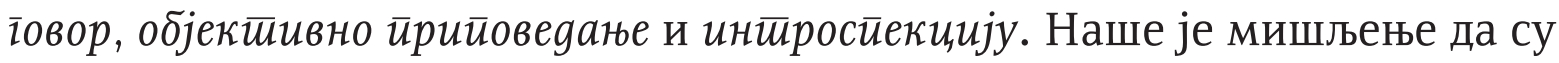
питања и задаци уз одломак добро осмишљени, прецизно формулисани и да помажу разумевању и тумачењу текста. Ипак, мислимо да је непотребно дугачак одломак који се нуди у уџбенику, јер се роман Корени обрађује у целини.

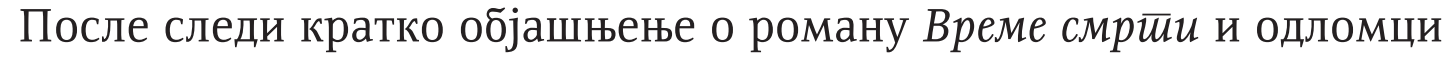
из дела на седам страна, уз објашњење непознатих речи на маргини: ge-

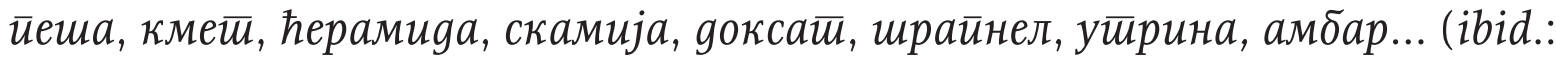
234-240), као и питања за његово тумачење (ibid.: 240-241). Занимљиво је да је у уџбенику много више места посвећено роману Корени и да је неупоредиво мање места остављено за роман Време смриии.

У уџбенику издавачке куће Логос делу Д. Ћосића посвећено је 17 страна (Петровић и др. 2016: 267-292). Прво се даје објашњење за роман Корени:

У роману Корени Добрице Ћосића упознаћеш се са кућом Катића, запазићеш колико социолошке, породичне и личне околности утичу на односе које њени чланови граде међу собом и са осталим сународницима. Један од највећих проблема тиче се неразумевања Аћима Катића, главе куће, са синовима Ђорђем и Вукашином, који су браћа-антиподи, а тензија је додатно подстакнута проблемом нерешеног питања потомства и наследника куће. Читајући следећи текст, у коме је приказано Бадње вече у кући Катића и долазак Вукашина Катића, запази модерност приповедачких техника у одломцима романа Корени (Петровић и др. 2016: 276),

${ }^{14}$ Било би занимљиво видети да ли је било измена у односу на ранија издања ове читанке. 
а затим следе одломци на седам страна, са илустрацијом Савамалске $\bar{u} u-$ шине Милића од Мачве из 1966. И поред најбоље воље, нисмо успели разумети зашто су се аутори одлучили за ову илустрацију. Одломак прати објашњење непознатих речи на маргини (астирахан, мuнgерлук, убалеїан,

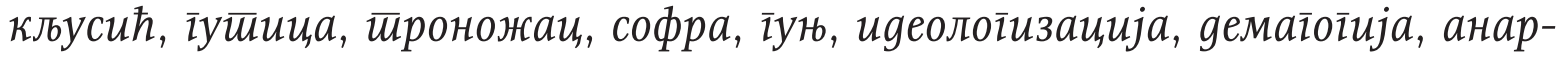

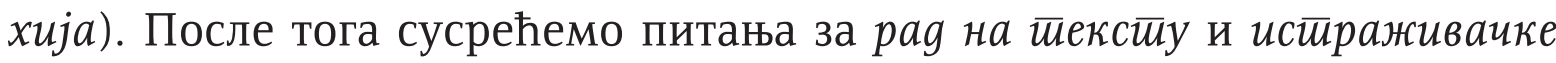
заgaйке. У њима се јасно издваја захтев „прочитај роман Корени Добрице Ћосића у целини". Питања и задатке који иду уз ово дело можемо сматрати добром основом за наставну обраду. Потом следе одломци из романа Време смрйи, али им претходи објашњење:

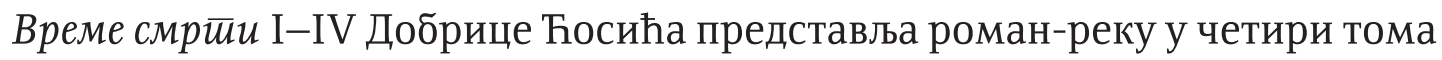
(1972-1979), роман-епопеју са темом Првог светског рата и стихијом историје, природе, друштва, појединца. У њему ћеш, поред јунака из преровских кућа Катића и Дачића, који су ти познати из романа Корени, пратити судбине бројних ликова, међу којима су хероји Ђачког батаљона, као и истакнуте историјске личности, попут Живојина Мишића и други. Читајући одломке из полифоног Ћосићевог дела, уочи како су све односи проблематизовани у приказаним историјским догађајима, ситуацијама, ликовима, њиховим личним и колективним биткама, посебно у контексту Аћима (деде), Вукашина (сина) и Ивана (унука) (Петровић и др. 2016: 285).

Опет сусрећемо уметничку слику Милића од Мачве, овог пута $\mathrm{Ha}$ леgеној уйрини (1974) и опет нам није најјаснија њена веза са одломком. Одломак прати објашњење непознатих речи и питања за рад на тексту, објашњење о Ђачком батаљону и објашњење књижевног термина роман-река.

Овде су дати одломци из прве и друге књиге романа Време смрйu. По нашим сазнањима, у школи се обрађује само једна књига, најчешће по избору предметних наставника.

\section{4. Закључна разматрања}

Дело Добрице Ћосића с правом се налази у наставним плановима и програмима за основну и средњу школу. Д. Ћосић је својим књижевним делом, у првом реду романима, обележио другу половину двадесетог века. Два његова романа добила су престижну НИН-ову награду за роман године и преведена су на тридесетак језика.

Мислимо и да је избор романа који се обрађује у настави добар и да су посреди његова најбоља књижевна дела. Истовремено, то су сведочанстава о два светска рата и свим превирањима која су она донела код српског сељака. Ћосићеви романи нуде бројна сведочанства о двадесетом веку код Срба - историјска, културолошка, социјална, политичка, 
етичка, психолошка... То пружа могућност да се реализују образовни, васпитни и практични циљеви наставе - што је њен примарни задатак.

Анализиране читанке уредно прате наставни програм, мада су неки поступци у њима помало нејасни. Читанке у осмом разреду основне школе и у четвртом разреду средње школе имају квантитативно неуједначен приступ Ћосићевом делу и волели бисмо да више личе једна на другу. Аутори читанки имају неуједначен приступ животу и делу писца, стиче се утисак да се више података нуди у читанкама за осми разред, што нам не изгледа логично. Неке читанке доносе велики број различитих година, а у некима се, по нашем приступу, непотребно инсистира на пишчевом политичком ангажовању. Укупан обим читанки за основну школу је уједначен и остаје нејасно зашто је осетна разлика у квантитативном приступу Ћосићевом делу. Слична је ситуација и код читанки за средњошколце.

Не можемо разумети како неке читанке које су штампане 2016. године не доносе податак о смрти писца. Ово је пропуст издавача у првом реду и волели бисмо да уџбеници немају оваквих мањкавости. Исти је поступак када су у питању књижевне награде. У неким читанкама нема податка да је Д. Ћосић добио НИН-ову награду за роман године, у некима има податка да је добитник, а у некима да је ту награду добио два пута. Ово сведочи о неуједначености, али и непотпуности наших уџбеника.

Читанке, тј. њихови аутори нису се јасно одредили ни према самим делима. Јасно је да се у осмом разреду обрађује одломак из романа Деобе, да се у четвртом разреду средње школе обрађује роман Корени, али је нејасно какав је статус романа Време смрйu, јер он има четири књиге. Ово оставља могућност да наставници сами одлучују и, по нашем сазнању, ту има доста неујеначености. Неспорно је да наставници могу имати слободу, али она, у оваквим случајевима, мора имати ограничења. Чини нам се да није добро да исти приступ романима Корени и Време смрйи буде и у гимназијама и у стручним школама.

\section{ИЗВОРИ И ЛИТЕРАТУРА}

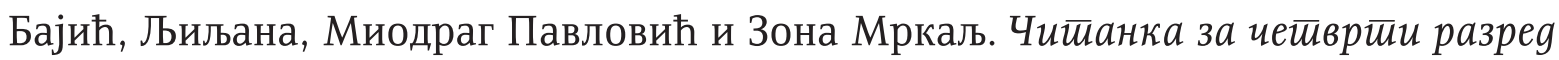
іимназија и среgюих ситручних школа. Београд: Klett, 2016. Шт.

Бајић, Љиљана, и Зона Мркаљ. Чийанка за 8. разреg основне школе. Београд: Завод за уџбенике, 2010. Шт.

Ивић, Иван, Ана Пешикан и Слободанка Антић. Воguи за gобар уибеник - ой-

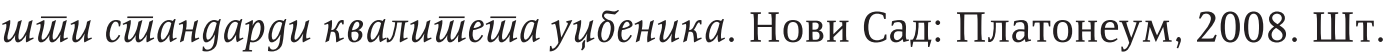

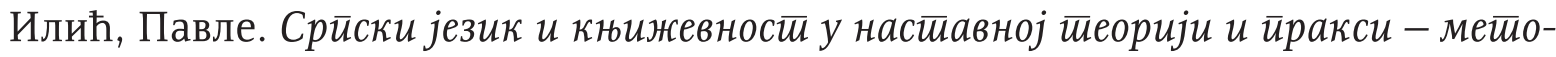
gика насйаве. Нови Сад: Прометеј, 1997. Шт.

ЛОТ. Лексикон образовних йермина. Београд: Учитељски факултет, 2014. Шт. 


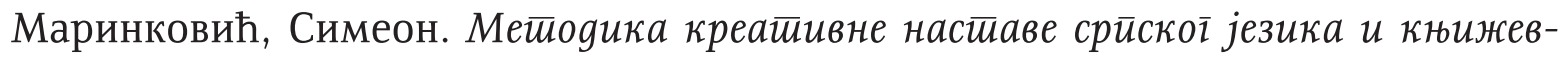
ностич. Београд: Креативни центар, 2003. Шт.

Несторовић, Зорица, и Златко Грушановић. Чийанка за 8. paзреg основне школе. Београд: Klett, 2016. Шт.

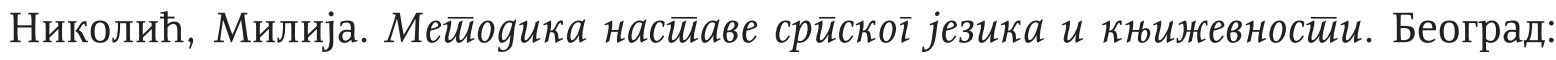
Завод за уџбенике и наставна средства, 1992. Шт.

Николић, Љиљана, и Босиљка Милић. Читианка са књижевнойеоријским йојмовима за IV paзpeg среgюе школе. Београд: Завод за уџбенике, 2016. Шт.

Павловић, Миодраг. Прииремане насйавника и ученика за йумачење књижевних gела. Београд: Завод за уџбенике, 2008. Шт.

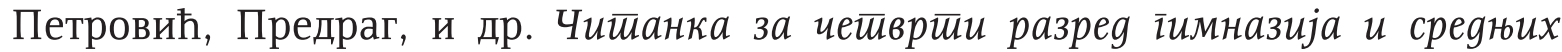
сиируиних школа. Београд: Логос, 2016. Шт.

Станковић Шошо, Наташа. Читианка за 8. paзpeg основне школе. Београд: Завод за уџбенике, 2016. Шт.

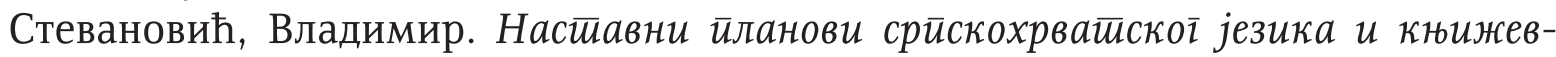
ностии за основну школу у СР Србији. Београд: Републички завод за унапређење васпитања и образовања, 1977. Шт.

Veljko Ž. Brborić

\section{LITERARY WORK OF DOBRICA ĆOSIĆ IN TEACHING}

\section{Summary}

This paper analyzes the work of Dobrica Ćosić in teaching process. We will review current curricula and see the participation of Dobrica Ćosić's writing in teaching. At the same time, we will also see the status of his work in teaching of the second half of the 20th century, i.e. when D. Ćosić entered the student's lecture and what changes have been taking place since then. After that, we will review the textbook literature and see its approach to the work of the famous writer. In our opinion, that will be sufficient to draw appropriate conclusions on the place and role of Dobrica Ćosić's writing in our primary and secondary schools, i.e. on the presence of his literary work in teaching. 